\title{
Morphological and Pomological Diversity among Hairy-Leaf Cross Berry (Grewia villosa Willd) Genotypes of Arid Kachchh, Gujarat, India
}

\author{
Rahul Dev $^{1 *}$, M. Sureshkumar ${ }^{1}$, K. Venkatesan ${ }^{2}$, Traloki Singh $^{1}$ and Devi Dayal ${ }^{1}$ \\ ${ }^{1}$ ICAR-Central Arid Zone Research Institute, Regional Research Station, \\ Kukma, Bhuj, Gujarat 370105, India \\ ${ }^{2}$ ICAR-Central Arid Zone Research Institute, Regional Research Station, \\ Jaisalmer- 345 001, Rajasthan, India \\ *Corresponding author
}

\section{A B S T R A C T}

This study was taken up as novel attempt toassess the genetic diversity of $G$. villosa in Kachchh regions of Gujarat, on basis of morphological and pomological characteristics,

\section{Keywords}

Arid zone, Cluster and PCA analysis, Genetic diversity, Grewia villosa, Variability

Article Info

Accepted:

10 December 2017

Available Online:

10 January 2018 for developing phenotypic markers. Field surveys conducted in arid region of Kachchh, Gujarat during March to October, 2015-16 and around twenty germplasm of G. villosa as fruits were collected from different habitats. Data on seventeen characters were recorded on its germination, growth and fruit parameters. High coefficient of variation (\%) in days to germination (75.5), number of leaves (56.5), petiole length (47.8), germination (46.3), number of branches per plant (43.3) and plant height (42.1) was found. Range of variation for plant height $(\mathrm{cm})$, number of fruits per $100 \mathrm{~g}(\mathrm{NF}), 1000$-seed weight (TSW) $(\mathrm{g})$ and fruit thickness $(\mathrm{mm})$ were observed with range (16.7 to $73.0,370$ to $620,114.0$ to 268.1 and 9.7 to 12.3 ) respectively. Range of value of Pearson's correlation coefficient varies from -0.70 in between stem girth and fruit thickness to 0.86 in between canopy spread N-S and E-W. Cluster analysis revealed the presence of four clusters at coefficient value of Euclidian distance of 6.4 with 1, 1, 2 and 16 genotypes, respectively. PCA analysis revealed the presence of $84.13 \%$ variability among $G$. villosa genotypes through first six most informative components and it also confirmed the clustering pattern obtained through cluster analysis.

\section{Introduction}

The India has around 31.8 million ha of land (12\% of total geographical area) as hot arid zone, which comprised with regions from Rajasthan, Gujarat, Punjab and Haryana. Vegetation and animal husbandry are the source of life support system of this arid zone of India, where animal husbandry depends entirely on natural vegetation. Genus "Grewia" (Tiliaceae) is one of the best examples of adaptive multipurpose plant species which are useful source of food, fodder, fiber, fuel wood, timber and wide range of traditional medicines. The Grewiavillosa (Luska) is a tropical plant species which can tolerate seasonal drought and withstand high temperature (Orwa et al., 
2009). It is usually a deciduous, muchbranched shrub growing from 1 - $4 \mathrm{~m}$ tall, though it sometimes becomes more tree-like and up to $4.5 \mathrm{~m}$ tall (Ruffo et al., 2002). The tree is naturally distributed in Tropical Africa (Mauritania, Egypt, Somalia, Namibia, Botswana and S. Africa), Arabia, Pakistan, Cape Verde Isles, East Indies and India where it found mostly onuplands, lower valley, along road side and field boundaries, up to $1,200 \mathrm{~m}$ elevations (von Maydell, 1990 and Kumar and Paul, 2015). It can grow in areas where the mean annual rainfall is in the range $200-800$ mm (Orwa et al., 2009 and Ruffo et al., 2002); thrives in black, sedimentary, stony and rocky, ferruginous soils (von Maydell, 1990). In India, it can be found in Andhra Pradesh, Bihar, Gujarat, Karnataka, Kerala, Madhya Pradesh, Maharashtra, Punjab, Rajasthan, Tamil Nadu and Uttar Pradesh.

It is a slow growing plant, its flowers are usually dioecious, though they are occasionally bisexual. Therefore, generally, both male and female forms need to be grown if fruit is required. Fruits yield little sweettasting pulp (Ruffo et al., 2002). The brittle fruit shell of dry fruits is discarded and the seeds are pounded before consumption. The roots are used to treat body pains. The bark is used in the treatment of wounds, syphilis and smallpox (von Maydell, 1990 and Ruffo et al., 2002). Grewia species can play effective role in rehabilitation of wastelands (Teketay, 1996). Though, the occurrences of wide natural diversity of Grewia villosa were reported [Tapkeshwari hill region (Patel et al., 2010), Tharawada-Gandher Reserve Forest (Patel et al., 2013a) and Dhinodhar hill (Patel et al., 2013b)], there has no attempt been made to explore and assess the amount of available genetic diversity. Hence, this paper is an attempt to assess genetic diversity in $G$. villosa on basis of morphological and pomological characteristics, and it would also help in developing adequate phenotypic markers for identification of promising genotypes and germplasm management.

\section{Materials and Methods}

\section{Experimental site}

The location of the study area was nursery and farm area of ICAR-CAZRI (Central Arid Zone Research Institute), Regional Research Station, Kukma-Bhuj, Gujarat (India). The climate of this Kachchh region is hot arid to semi-arid with a maximum temperature of $48^{\circ} \mathrm{C}$ during summer and minimum $2^{\circ} \mathrm{C}$ during winter. The average rainfall of Kachchh is $385 \mathrm{~mm}$ (average of 1998 to 2016) and most of rainy days occur during July to September with high evapotranspiration that ranges from 1500-2000 $\mathrm{mm}$ per year. The characteristic of rainfall is scanty, erratic and irregular (coefficient of variation as $71.25 \%$ ).

\section{Field survey, collection and evaluation}

Field surveys were conducted in arid region of Kachchh $\left(23^{\circ} \mathrm{N}\right.$ latitude, $69^{\circ} \mathrm{E}$ longitude), Gujarat for the collection of $G$. villosa accessions during summer and monsoon season of year, 2015 from the months of March to October. The primary selection criterion was based on fruit and yield attributes of the genotypes. Twenty germplasm of $G$. villosa as fruits were collected from different sites.

These collected germplasm were evaluated in nursery and field conditions. Germination studies were conducted by sowing twenty seeds of each accessions in polythene bags (size: $15 \times 10 \mathrm{~cm}$ ), filled with sand, soil and farm yard manure (FYM) in 1:2:1 ratio. Seeds were also sown in portray having coco-peat, vermiculite and perlite (2:1:1 ratio) as supportive materials. Two seeds were sown in each bag and portrays compartment and kept in shade net house (50\% sun light) and were 
irrigated with normal tap water daily until seeds germinate.

Totally, sixteen characters were observed on collected germplasm of $G$. villosa. Five different fruit characters of collected genotypes viz., 1000-fruit weight (g), diameter $(\mathrm{mm})$, length $(\mathrm{mm})$, width $(\mathrm{mm})$ and number of fruits per $100 \mathrm{~g}$ were measured in laboratory after collection and these observations taken on fifty fruits per accession. The measurement of fruit length was made on the polar axis, i.e. between the apex and stylar end. The maximum width of the fruit was measured in the direction perpendicular to the polar axis with a digital vernier caliper (Gogu et al., 2009). Germination percent and days to germination were observed on collected germplasm at nursery. Nine different growth parameters such as plant height $(\mathrm{cm})$, canopy spread (N-S and E-W), number of branches per plant, number of leaves, stem girth $(\mathrm{mm})$, leaf length $(\mathrm{mm})$, leaf width $(\mathrm{mm})$, petiole length $(\mathrm{mm})$ and petiole thickness $(\mathrm{mm})$ were estimated at monthly interval in the nursery as well as in one year old plants at field.

\section{Data analysis}

The experiment was conducted under randomized block design with three replication and replicated data were analyzed as per the method suggested by Gomez and Gomez (1984). Data recorded were subjected to statistical analysis such as descriptive statistics, Pearson's correlation and multivariate analysis by using the software package "PAST3" (Hammer et al., 2001).

\section{Results and Discussion}

\section{Range of variation}

The growth and fruit characters of twenty collected germplams of Grewia villosa are subjected to descriptive statistics revealed the presence of considerable amount of variation among them on basis of coefficient of variation $(\mathrm{CV})$, which ranged from 6.8 to 75.5 (Table 1). The characters with high amount of variation among genotypes are: days to germination (75.5), number of leaves (56.5), petiole length (47.8), germination (46.3) and least observed on fruit thickness (6.8). Though fruit characters showed little variation, the considerable amount of variation were observed on 1000-fruit weight (14.5) and number of fruits per $100 \mathrm{~g}$ (12.6) among genotypes. Germination (\%) ranged from 10 to 60 with mean of 33.8 among twenty genotypes under study. Maximum germination was observed on genotypes CZBGV 11 and CZBGV 12 (60\%) followed by CZBGV 13 $(55 \%)$ and least was found in CZBGV 10 $(10 \%)$. The plant height of these genotypes was varied from 16.67 to $73.0 \mathrm{~cm}$ with mean of $35.5 \mathrm{~cm}$. The maximum plant height was observed in genotype CZBGV $23(73.0 \mathrm{~cm})$ followed by CZBGV $19(61.0 \mathrm{~cm})$ and CZBGV $24(60 \mathrm{~cm})$, whereas, minimum growth obtained in CZBGV $4(16.67 \mathrm{~cm})$. Horizontal plant growth of nine months old plant with respect of plant spread (N-S and E$\mathrm{W})$ was reported maximum in genotype CZBGV 23 (46.0 and $51.67 \mathrm{~cm}$, respectively) followed by CZBGV 25 (40.0 and $42.33 \mathrm{~cm}$ ) and minimum was found in CZBGV 1 (10.33 and $11.0 \mathrm{~cm}$ ). Plant vigour in terms of number of branches and leaves per plant was reported maximum in genotype CZBGV 23 (17.67 and 152 respectively) CZBGV 13 (14.50 and 104.5) and minimum number of branches (3.3) and number of leaves (22) was reported in CZBGV 18 and CZBGV 16, respectively.

Fruit characteristics are associated with fruit yield and fruit yield is as considered the most important economic characters while making selection/hybridization for crop improvement. A wide range of variability for different fruit characters was observed among the selected genotypes. The range and mean value of 
number of fruits per $100 \mathrm{~g}$ was observed as 370 to 620 and 472.2, respectively. The maximum number of fruits per $100 \mathrm{~g}$ was reported in CZBGV16 (620), followed by CZBGV 20 (600) and CZBGV 24 (520). However, the minimum no of fruits / $100(\mathrm{~g})$ was noted under CZBGV 23 (370). The fruit dimensions in terms of fruit thickness, length and width was reported maximum in CZBGV 22 (12.33, 10.0 and $10.33 \mathrm{~mm}$ respectively) followed by CZBGV 16 (12.0, 10.0 and $10.33 \mathrm{~mm}$ respectively) and minimum value was noted in CZBGV 18 (9.67, 7.67 and $8.0 \mathrm{~mm}$ respectively). The fruits were measured for 1000 fruit weight. It was found that it varied from 114 to $268(\mathrm{~g})$. The maximum fruit weight (1000 fruit weight) was observed in CZBGV 23 (268.13), followed by CZBGV 1 $(253.43 \mathrm{~g})$, and CZBGV $14(252.33 \mathrm{~g})$. However, minimum fruit weight was noted in CZBGV 20 (114 g). Similar kind of results were reported by Chatti et al., (2008) and Gaaliche et al., (2012) in fig collection and by Mratinić et al., (2011) in Apricot.

Skewness describes the normal distribution pattern of data with respect to its dispersion from the mean. Skewness value expressed that data were normally skewed for all the parameter which was less than +2 , except for petiole length (2.3). However, positive skewness value observed for most of the parameters i.e. germination (\%), days to germination, plant height, plant spread (N-S \& $\mathrm{E}-\mathrm{W})$, number of branches per plant, number of leaves, stem girth, leaves length, petiole length, petiole thickness, number of fruits per $100 \mathrm{~g}$ and fruit length.

Positive skewness is associated with complementary gene interactions while negative skewness is associated with duplicate (additive $\times$ additive) gene interactions. The genes controlling the trait with skewed distribution tend to be predominantly dominant irrespective of whether they have increasing or decreasing effect on the trait. Kurtosis is describes the shape of a probability distribution. The fruit and plant evaluation data show platykurtic distribution pattern for germination (\%), days to germination, plant height, plant spread (N-S), number of branches per plant, leaves length, leaves width, number of fruits per plant, while leptokurtic distribution pattern was noted for plant spread (E-W), number of leaves, petiole length, 1000 fruit weight. Kurtosis is negative or close to zero indicates the absence of gene interaction, whereas, its positive vale indicates the presence of gene interactions. The traits with leptokurtic and platykurtic distribution are controlled by fewer and large number of genes, respectively.

\section{Pearson's correlation analysis}

Pearson's correlation matrices of plant growth and fruit characters of $20 \mathrm{G}$. villosa genotypes are presented in Table 2. Range of value of correlation coefficient varies from -0.70 in between stem girth and fruit thickness to 0.86 in between canopy spread N-S and E-W. The number of fruits per $100 \mathrm{~g}$ showed highly significant negative correlation with canopy spread [N-S (-0.41) and E-W (-0.44)], number of branches (-0.51) and number of leaves (0.48). Though, number of fruits per $100 \mathrm{~g}$ showed highly significant negative correlation $(-0.65)$ with 1000 -fruit weight, fruit length and width showed significantly positive correlation (0.43 and 0.47 , respectively).In any fruit crop, fruit weight can be used for the development of high yield. Being apolygene trait, direct improvement in yield is difficult and the traits which have high correlation with the yield might prove helpful to improve the yield indirectly (Ojaghi and Akhundova, 2010). Thus it was not surprising that positive and significant associations were observed between 1000-fruit weight and fruit yield related characters (fruit thickness, fruit length and width). 
Table.1 Range of variation in plant and fruit characteristic of 20 Grewia villosa genotypes collected from arid Kachchh of Gujarat

\begin{tabular}{|c|c|c|c|c|c|c|c|c|}
\hline & Min & Max & Mean & $\begin{array}{l}\text { Std. } \\
\text { error }\end{array}$ & $\begin{array}{l}\text { Std. } \\
\text { dev }\end{array}$ & $\begin{array}{c}\text { Skew- } \\
\text { ness }\end{array}$ & $\begin{array}{l}\text { Kurt- } \\
\text { osis }\end{array}$ & CV \\
\hline Germination (\%) & 10.0 & 60.0 & 33.8 & 3.5 & 15.6 & 0.4 & -1.2 & 46.3 \\
\hline Day to germination & 21.3 & 176.7 & 58.6 & 9.9 & 44.3 & 1.8 & 2.3 & 75.5 \\
\hline Plant height (cm) & 16.7 & 73.0 & 35.5 & 3.3 & 15.0 & 1.1 & 1.0 & 42.1 \\
\hline Plant spread (N-S) & 10.3 & 46.0 & 26.5 & 2.1 & 9.5 & 0.4 & -0.4 & 36.0 \\
\hline Plant spread (E-W) & 11.0 & 51.7 & 24.1 & 2.1 & 9.4 & 1.6 & 3.4 & 38.9 \\
\hline Number of branch/Plant & 3.3 & 17.7 & 8.8 & 0.9 & 3.8 & 0.8 & 0.0 & 43.3 \\
\hline Number of leaves & 22.0 & 152.0 & 56.1 & 7.1 & 31.7 & 1.7 & 3.3 & 56.5 \\
\hline Stem girth & 2.0 & 3.8 & 2.8 & 0.1 & 0.5 & 0.2 & -1.0 & 18.1 \\
\hline Leave length (mm) & 30.3 & 52.4 & 36.1 & 1.3 & 5.7 & 1.6 & 2.5 & 15.7 \\
\hline Leave width (mm) & 20.4 & 46.2 & 32.6 & 1.5 & 6.5 & -0.1 & 0.1 & 20.0 \\
\hline Petiole length (mm) & 3.9 & 21.3 & 8.1 & 0.9 & 3.9 & 2.3 & 7.0 & 47.8 \\
\hline Petiole thickness (mm) & 0.6 & 1.4 & 0.9 & 0.1 & 0.2 & 0.4 & -0.9 & 26.1 \\
\hline Number of fruit / $100 \mathrm{~g}$ & 370.0 & 620.0 & 472.2 & 13.3 & 59.5 & 1.0 & 1.7 & 12.6 \\
\hline 1000 Fruit weight & 114.0 & 268.1 & 222.0 & 7.2 & 32.3 & -1.9 & 6.1 & 14.5 \\
\hline Fruit thickness (mm) & 9.7 & 12.3 & 11.1 & 0.2 & 0.7 & -0.5 & -0.5 & 6.8 \\
\hline Fruit length (mm) & 7.7 & 10.7 & 9.0 & 0.2 & 0.8 & 0.1 & -0.3 & 9.1 \\
\hline Fruit width (mm) & 8.0 & 11.0 & 9.9 & 0.2 & 0.8 & -0.7 & 0.0 & 8.3 \\
\hline
\end{tabular}


Table.2 Pearson's correlation coefficient for quantitative traits of 20 Grewia villosa genotypes

\begin{tabular}{|c|c|c|c|c|c|c|c|c|c|c|c|c|c|c|c|c|}
\hline & GP & DTG & PH & PS1 & PS2 & $\mathrm{NBr}$ & NL & SG & $\mathbf{L L}$ & LW & PL & PT & NFr & TSW & FT & FL \\
\hline \multicolumn{17}{|l|}{ GP } \\
\hline DTG & -0.41 & & & & & & & & & & & & & & & \\
\hline $\mathbf{P H}$ & 0.11 & -0.34 & & & & & & & & & & & & & & \\
\hline PS1 & 0.17 & -0.24 & 0.76 & & & & & & & & & & & & & \\
\hline PS2 & -0.03 & -0.16 & 0.76 & 0.86 & & & & & & & & & & & & \\
\hline $\mathrm{NBr}$ & 0.26 & -0.04 & 0.55 & 0.61 & 0.69 & & & & & & & & & & & \\
\hline $\mathbf{N L}$ & 0.21 & -0.18 & 0.71 & 0.81 & 0.85 & 0.77 & & & & & & & & & & \\
\hline SG & 0.33 & -0.28 & 0.08 & 0.09 & 0.00 & 0.01 & 0.11 & & & & & & & & & \\
\hline $\mathbf{L L}$ & -0.19 & 0.11 & -0.10 & -0.13 & -0.14 & -0.22 & -0.20 & 0.31 & & & & & & & & \\
\hline $\mathbf{L W}$ & 0.29 & -0.28 & 0.35 & 0.38 & 0.27 & 0.37 & 0.54 & 0.49 & 0.04 & & & & & & & \\
\hline PL & 0.29 & -0.24 & 0.21 & 0.20 & -0.10 & -0.21 & -0.03 & 0.52 & 0.38 & 0.29 & & & & & & \\
\hline PT & -0.16 & -0.03 & -0.03 & 0.04 & -0.18 & -0.44 & -0.25 & -0.17 & 0.24 & -0.21 & 0.44 & & & & & \\
\hline $\mathrm{NFr}$ & -0.12 & -0.02 & -0.26 & -0.41 & -0.44 & -0.51 & -0.48 & 0.18 & -0.01 & -0.11 & 0.25 & 0.22 & & & & \\
\hline TSW & 0.14 & 0.07 & 0.14 & 0.13 & 0.17 & 0.23 & 0.21 & -0.39 & -0.02 & -0.28 & -0.12 & -0.07 & -0.65 & & & \\
\hline FT & -0.30 & 0.16 & -0.06 & -0.10 & 0.12 & 0.04 & 0.06 & -0.70 & -0.08 & -0.14 & -0.47 & -0.04 & -0.05 & 0.18 & & \\
\hline FL & -0.11 & 0.17 & -0.29 & -0.34 & -0.16 & -0.14 & -0.23 & -0.42 & -0.12 & -0.19 & -0.27 & -0.31 & -0.03 & 0.43 & 0.61 & \\
\hline FW & 0.06 & 0.22 & -0.01 & -0.09 & 0.15 & 0.12 & 0.10 & -0.44 & -0.18 & -0.13 & -0.26 & -0.39 & -0.31 & 0.47 & 0.64 & 0.74 \\
\hline
\end{tabular}

Table.3 The cumulative (\%) variance of first three Principal components obtained through PCA analysis of 20 Grewia villosa genotypes

\begin{tabular}{|c|c|c|}
\hline Principal component & $(\%)$ Variance & Cumulative (\%) Variance \\
\hline I & 27.30 & 27.30 \\
\hline II & 23.14 & 50.44 \\
\hline III & 11.48 & 61.92 \\
\hline IV & 8.41 & 70.33 \\
\hline V & 7.09 & 77.42 \\
\hline VI & 6.71 & 84.13 \\
\hline
\end{tabular}


Fig.1 Dendrogram of 20 Grewia villosa genotypes based on UPGMA method of cluster analysis using Euclidian distance

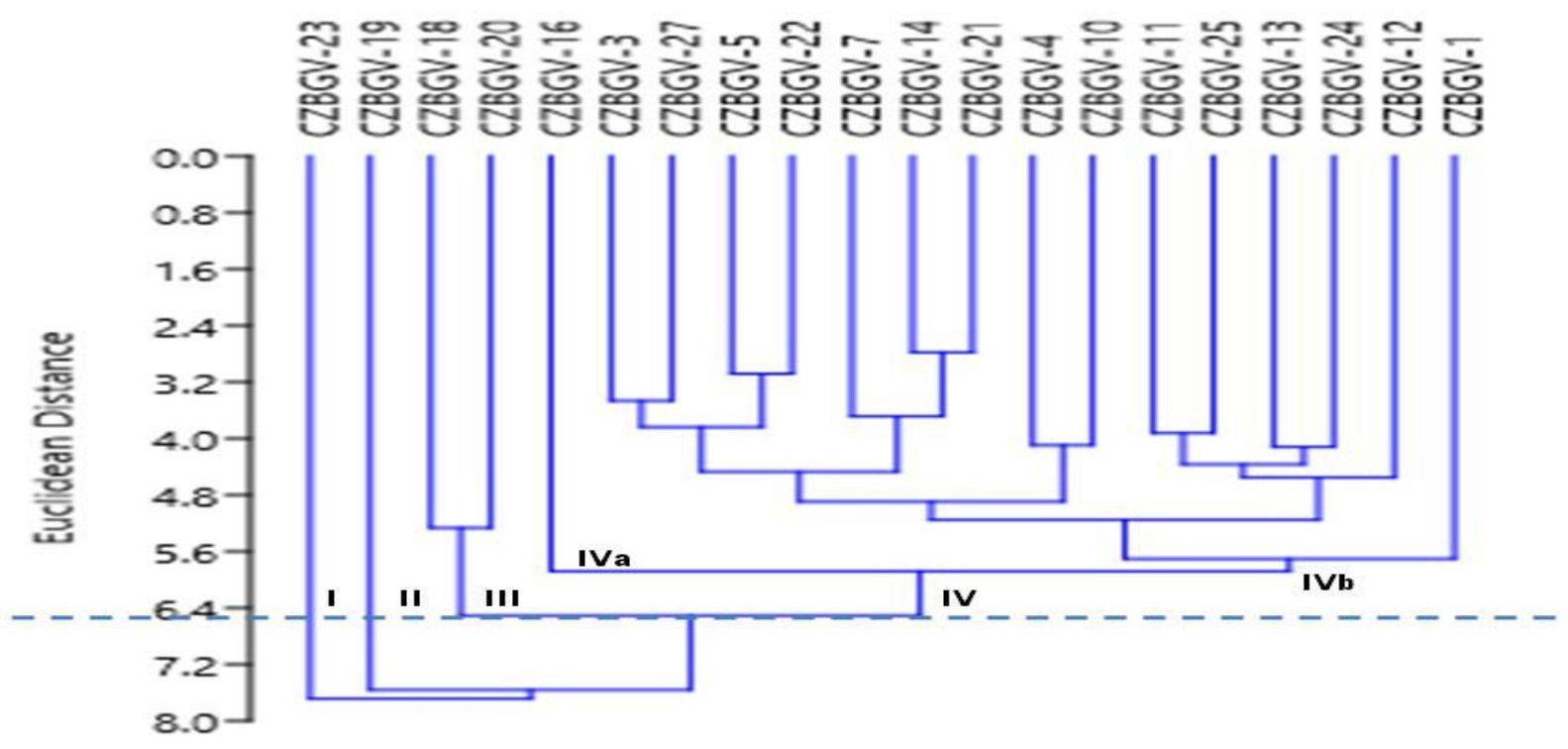

Fig.2 Segregation of 20 Grewia villosagenotypes according to their pomological and morphological characteristicsdetermined by principal component analysis (PCA). Vectors represent the loadings of phenological and quantitative traits data alongwith principal component scores

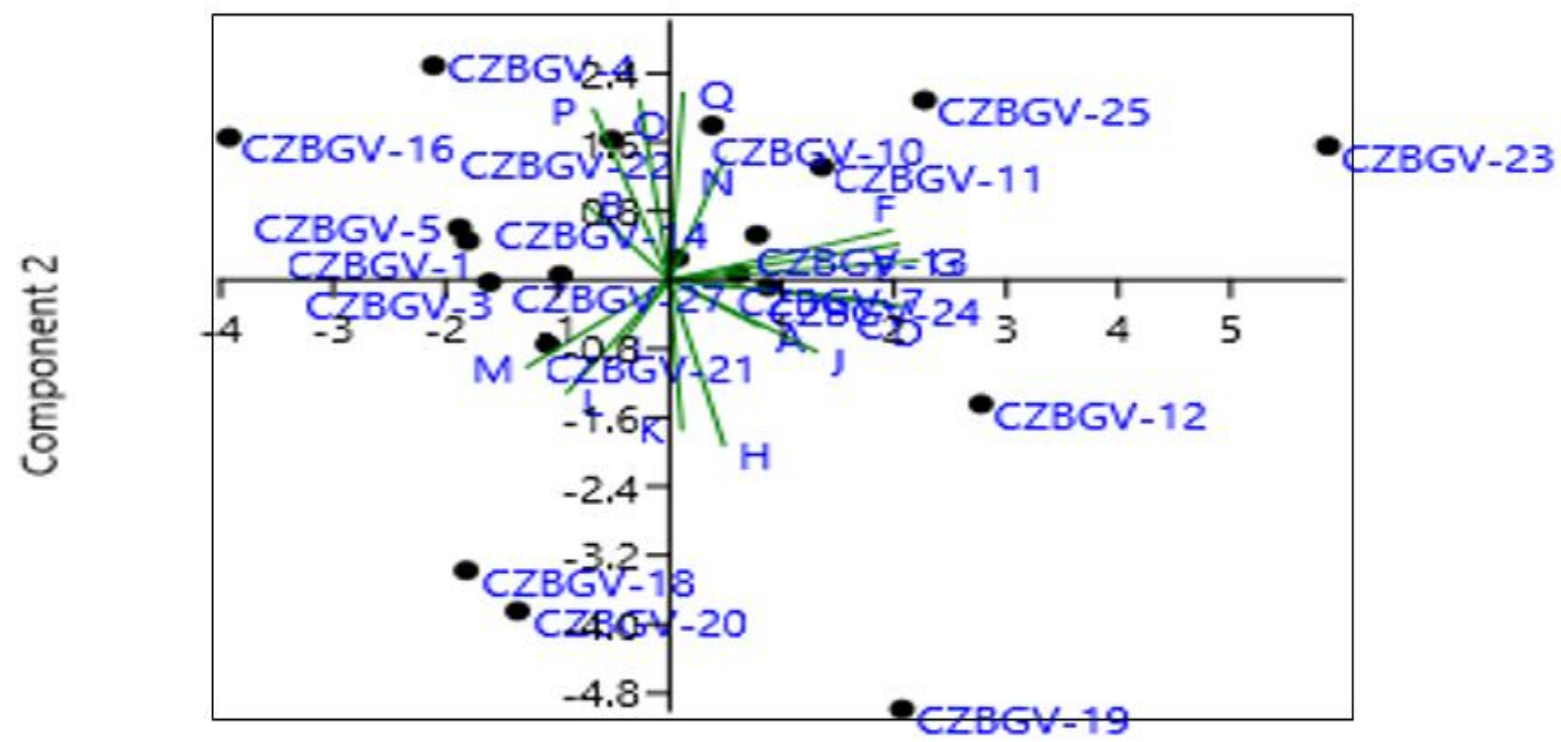

Component 1

[Abbreviations in biplot are:A: Germination (\%); B: Day to germination; C: Plant height (cm); D: Plant spread (NS); E: Plant spread (E-W); F: Number of branch/ Plant; G: Number of leaves/ Plant; H: Stem girth (mm); I: Leave length (mm); J: Leave width (mm); K: Petiole length (mm); L: Petiole thickness (mm); M: Number of fruit / 100 (g); N: 1000 Fruit weight (g); O: Fruit thickness (mm); P: Fruit length (mm); Q: Fruit width (mm)]. 


\section{Cluster analysis}

The dendrogram of $20 \mathrm{G}$. villosa genotypes generated using UPGMA method of cluster analysis on basis of Euclidean distance classified these genotypes into four clusters at Euclidean coefficient of 6.4 (Fig. 1). The clusters I and II consisted only one genotype each as CZBGV 23 and CZBGV 19, respectively. The genotype $\mathrm{CZBGV} 23$ characterized by its tallest height, highest plan spread (N-S and E-W), number of leaves/ plant and 1000 fruit weight, however number of fruits $/ 100(\mathrm{~g})$ was less, that means size of fruit would be better. In general, the morphological traits i.e. plant height, plant spread, number of branches/ plant, number of fruits/ $100(\mathrm{~g})$, fruit dimension (thickness, length and width) played a significant role in bunching of Grewia villosa genotypes into different clusters. The genotype CZBGV 19 had high plant height, plant spread, leave length and width and number of fruit / plant.

Probable factors that may have played a role in high level of differentiation in some genotypes/ populations are breeding system and genetic drift (Gharibi et al., 2011). The clusters III and IV consists two (CZBGV 20 and CZBGV 18) and sixteen genotypes, respectively. The cluster IV was divided further into two sub clusters (sub-cluster IVa and IVb) with one (CZBGV 16) and 15 (CZBGV1, CZBGV 12, CZBGV 24, CZBGV 13, CZBGV 25, CZBGV 11, CZBGV 10, CZBGV 4, CZBGV 21, CZBGV 14, CZBGV 7, CZBGV 22, CZBGV 5, CZBGV 27 and CZBGV 3) genotypes, respectively. The genotype CZBGV 16 had highest number of fruits/100 $\mathrm{g}$ and fruit thickness, length and width, while medium plant height, spread, and leaf area (length and width). The genotype CZBGV 1had high number of fruits/ $100 \mathrm{~g}$, fruit thickness, fruit length and fruit width and 1000 fruit weight, whereas, the remaining 14 genotypes (CZBGV 3, CZBGV 27, CZBGV
5, CZBGV 5, CZBGV 22, CZBGV 7, CZBGV 14, CZBGV 21, CZBGV 4, CZBGV 10, CZBGV 11, CZBGV 25, CZBGV 13, CZBGV 24, CZBGV 12) possessed average plant height, plant spread, number of leaves, medium number of fruit/ $100(\mathrm{~g}), 1000$ fruit weight, fruit length, fruit thickness, and fruit width. Similar kind of grouping pattern on basis of morphological and pomological traits were reported for cluster analysis in fruit crops viz., Apricot (Ashma et al., 2005; Mratinic et al., 2011; Kumar et al., 2015) and wild hip rose (Verma et al., 2015).

\section{Principal component analysis}

Principal components analysis identifies the patterns in data, these principal components expresses data in such a way as to highlight their similarities and differences (Mattos et al., 2010; Milosevic, 2010). Hence, principal component analysis was done to find the dominant traits contributed to the principal components (Fig. 2). The PCA analysis performed on 17 quantitative traits of $G$. villosa revealed that first six most informative components accounted $84.13 \%$ of the variability. PC1, PC2, PC3, PC4, PC5 and PC6 accounted for $27.30 \%, 23.14 \%$ and $11.48 \%, 8.41,7.09$ and 6.71 with Eigen values 4.84, 4.10, 2.04, 1.491 .26 and 1.19 respectively. Principal components analysis reduced the original 17 characters in experiment to six principal components. The first six principal components with Eigen values $>1$ was interpreted for variation among 20 G. villosa accessions (Table 2). The eigen value helps in determining the numbers to be retained. The first PC, which is the most important component, explained $27.30 \%$ of total variation and was positively related to germination (\%), plant height $(\mathrm{cm})$, plant spread $(\mathrm{N}-\mathrm{S})$, plant spread (E-W), number of branch/Plant, number of leaves and leave width $(\mathrm{mm})$, and negatively related to number of fruit / $100(\mathrm{~g})$ and fruit length $(\mathrm{mm})$. The 
PC2 accounted of $23.14 \%$ of the total variation and the characters with the greatest weight on this component were fruit thickness $(\mathrm{mm})$, fruit length $(\mathrm{mm})$, fruit width $(\mathrm{mm})$, days to germination and number of branch/plant. The PC3 accounted for $11.48 \%$ and positively related to petiole thickness $(\mathrm{mm})$ plant height $(\mathrm{cm})$, and plant spread $(\mathrm{N}-$ $\mathrm{S})$. However, PC4 accounted for $8.41 \%$ and positively related to germination $(\%), 1000$ fruit weight, fruit length $(\mathrm{mm})$ and fruit width $(\mathrm{mm})$ and negatively associated to number of fruit/100 (g). While studies in strawberry (Hofer et al., 2012) and apricot (Bahadur and Meena, 2016) found a cumulative variability between 30.05 to $78 \%$ for first three components, the results obtained in the present study (61.92 and $84.13 \%$ for first three and six principal components, respectively) corresponds well to it, which also validated by results of Mratinić et al., (2011) and Kumar et al., (2015) for Apricot (>80\% and $73.44 \%$, respectively).

The diversity study based on morphological and pomological traits of twenty Grewia villosa genotypes revealed the presence of considerable amount of genetic variability between them. The cluster analysis classified genotypes into four different groups according to their pomological and morphological characteristics in which genotypes present in Cluster-I and II having better growth and fruit characters, whereas, Cluster-IV having genotypes with average growth and fruit characters. Principal component analysis (PCA) revealed that traits related to petiole length, fruit length, fruit thickness, number of fruits, thousand seed weight, stem girth, leaf length and width accounted for distinct variability among different genotypes. This may be used for identification of promising genotypes on basis of pomological characters and also to utilize the dominant traits that contributing to genetic variability.

\section{References}

Asma B.M. and Ozturk K. 2005. Analysis of mrphological, pomological and yield characteristics of some apricot germplasm in Turkey. Genetics Resources and Crop Evolution 52: 30513.

Bahadur, V. and Meena, O.P. 2016. Genetic diversity analysis of indigenous turmeric genotypes using horticultural markers. Indian J. Hort. 73(4): 538-543. DOI: 10.5958/0974-0112.2016.00112.2

Gaaliche, B., Saddoud, O. and Messaoud Mars. 2012. Morphological and Pomological Diversity of Fig (Ficus carica L.) Cultivars in Northwest of Tunisia. ISRN Agronomy. Article ID 326461: 1-9. doi:10.5402/2012/326461.

Hammer $\varnothing$, Harper D.A.T., Ryan, P.D. 2001. PAST: Paleontological Statistics Software Package for Education and Data Analysis. Palaeontologia Electronica 4: 1-9.

Kumar, A and Paul, T.K. 2015. Grewia villosa Willdenow (Malvaceae): a new record from Eastern India. Pleione 9(1): 240 - 243.

Kumar, D., Lal, S. and Ahmed, N. 2015. Morphological and pomological diversity among apricot (Prunus armeniaca) genotypes grown in India. Indian J. Agric. Sci. 85 (10): 1349-55.

Mars, M., Chatti, K., Saddoud, O., SalhiHannachi, A., Trifi, M. and Marrakchi, M. 2008. Fig cultivation and genetic resources in Tunisia, an overview, Acta Horticulturae, 798: 27-32.

Mattos, A.L Amorim, P.E., Amorim, O.B.V., Cohen, O.K., Lodo, S.A.C and Silva, S.O. 2010. Agronomical and molecular characterization of banana germplasm. Pesquisa Agropecuária Brasileira. 45: 146-54.

Miloševic T, Miloševic N, Glišic I and Krška B. 2010. Characteristics of promising 
apricot (Prunus armeniaca L.) genetic resources in Central Serbia based on blossoming period and fruit quality. Hort Science 37: 46-55

Mratinic E, Popovski B, Milosevic T and Popovska. 2011. Analysis of morphological pomological characteristics of apricot germplasm in FYR Macedonia. Journal Agric. Sci. and Tech. 13: 1 121-34.

Ojaghi J, Akhundova E. 2010. Genetic diversity in doubled haploids wheat based on morphological traits, gliadin protein patterns and RAPD markers. Afr. J. Agric. Res. 5(13): 1701-1712.

Orwa. C., Mutua, A., Kindt, R., Jamnadass, R., Anthony, S. 2009. Agroforestree Database: a tree reference and selection guide version 4.0 (http://www.world agroforestry.org/sites/treedbs/treedata bases. asp)

Patel, R., Roy Mahato, A.K., Vijay Kumar, V. and Asari, R.V., 2013b. Status of the medicinal plants in Tharawada-Gandher Reserve Forest of Kachchh, Gujarat and the ethnomedicinal practices of local community. Journal of Medicinal Plants Studies 1(4): 1-10.

Patel, Y., Patel, R.M., Roy Mahato, A.K. and
Joshi, P.N. 2013b. Status and diversity of ethno-medicinal plants of Dhinodhar hill, Kachchh district, Gujarat. International Journal of Plant, Animal and Environmental Sciences 3(1): 265273.

Patel, Y.S., Joshi, E.P. and Joshi, P.N. 2010. Ethnobotanical Study of Tapkeshwari Hill, Bhuj, Kachchh, India. Life Sciences Leaflets, 2: $22-31$.

Ruffo, C.K., Birnie, A. and Tengnas, B. 2002. Edible Wild Plants of Tanzania, Regional Land Management Unit; Nairobi. ISBN 9966-896-60-0

Teketay, D. 1996. Germination ecology of twelve indigenous and eight exotic multipurpose leguminous species from Ethopia. For. Ecol. Manage 80:209-223.

Verma, M.K., Lal, S., Ahmed, N., Kumar, D., Singh, D.B., Sagoo, PA. 2015. Genetic diversity among native wild hip rose (Rosa canina L.) genotypes collected from Kashmir valley. Indian J. Hort. 72 (2): 250-256.

Von Maydell, H. 1990. Trees and Shrubs of the Sahel. Their Characteristics and Uses. Deutsche Gesellschaft fur Technische Zusammenarbeit; Germany. ISBN: 3-8236-1198-4

\section{How to cite this article:}

Rahul Dev, M. Sureshkumar, K. Venkatesan, Traloki Singh and Devi Dayal. 2018. Morphological and Pomological Diversity among Hairy-Leaf Cross Berry (Grewia villosa Willd) Genotypes of Arid Kachchh, Gujarat, India. Int.J.Curr.Microbiol.App.Sci. 7(01): 11631172. doi: https://doi.org/10.20546/ijcmas.2018.701.141 